\title{
Evaluation of (anti)genotoxic activities of Phyllanthus niruri L. in rat bone marrow using the micronucleus test
}

\author{
Fernando Márlisson de Queiroz, Kayo Wanderson de Oliveira Matias, Mylena Mylana Freire da \\ Cunha, Aline Schwarz"
}

Department of Clinical and Toxicological Analyses, Federal University of Rio Grande do Norte

\begin{abstract}
Phyllanthus niruri L. (Euphorbiaceae), known as "quebra-pedra" (Portuguese for "stonebreaker"), is an herb used for kidney disorders. In light of its frequent use by the population, the present study aimed to investigate the genotoxic, antigenotoxic and cytotoxic activities of a standardized $P$. niruri extract in bone marrow rats. Three groups of 12 animals were treated daily by gavage over a period of 30 days, with 50 , 150 or $250 \mathrm{mg} / \mathrm{kg}$ of $P$. niruri extract aqueous solution. The control group $(\mathrm{n}=12)$ received tap water. At the end of treatment (day 31 ), groups were divided into two minor subgroups ( $n=6 /$ group) and received cyclophosphamide $(50 \mathrm{mg} / \mathrm{kg}$, i.p.) or saline $0.9 \%$ (i.p.). After 24 hours, we evaluated the frequency of micronucleated polychromatic erythrocytes for each animal (MNPCE) at 1000 PCE. Cytotoxicity was evaluated with the PCE/NCE ratio ( $\mathrm{NEC}=$ normochromatic erythrocytes). General toxicity was assessed during treatment using the parameters of body weight gain, ration and water consumption. The dry extract did not provoke changes in body weight, weight gain, ration and water intake or changes in the frequency of MNPCE or cytotoxicity in bone marrow. We propose that the $P$. niruri extract used here showed no genotoxic, antigenotoxic and cytotoxic activities under the experimental conditions.
\end{abstract}

Uniterms: Phyllanthus niruri L./genotoxicity. Phyllanthus niruri L./toxicological analysis/experimental study. Medicinal plantas/evaluation.

Phyllanthus niruri L. (Euphorbiaceae), conhecida como "quebra-pedra", é uma planta medicinal utilizada frequentemente pela população no tratamento de problemas renais. Foram avaliadas as atividades genotóxicas, antigenotóxicas e citotóxicas de um extrato padronizado dessa espécie em ratos. Três grupos de doze animais foram tratados durante trinta dias, por gavagem, com 50, 150 ou $250 \mathrm{mg} / \mathrm{kg} / \mathrm{dia}$ de solução aquosa do extrato de $P$. niruri e um grupo controle $(\mathrm{n}=12)$ recebeu água destilada pela mesma via. No final do tratamento os grupos foram divididos em dois subgrupos (6 animais/grupo) e receberam uma dose única de ciclofosfamida $(50 \mathrm{mg} / \mathrm{kg}$, i.p.) ou de solução salina $0,9 \%$ (i.p.). Após 24 horas, a frequência de eritrócitos policromáticos micronucleados (EPCMN) foi avaliada em 1000 EPC. A citotoxicidade foi avaliada pela relação entre eritrócitos policromáticos e normocromáticos (EPC/ ENC) e a toxicidade geral foi avaliada através dos parâmetros de ganho de peso corporal, consumo de ração e ingestão hídrica. O extrato seco não provocou alterações significativas no peso corporal, ganho de peso e consumo de ração em relação ao grupo controle, nem alterações na frequência de EPCMN ou citotoxicidade em medula óssea. Dessa maneira, pode-se concluir que $P$. niruri não apresentou atividades genotóxica, antigenotóxica e/ou citotóxica nas condições experimentais executadas.

Unitermos: Phyllanthus niruri L./genotoxicidade. Phyllanthus niruri L./análise toxicological/estudo experimental. Plantas medicinais/avaliação.

\footnotetext{
*Correspondence: A. Schwarz. Departamento de Análises Clínicas e Toxicológicas, Centro de Ciências da Saúde, Faculdade de Farmácia, Universidade Federal do Rio Grande do Norte. Rua General Gustavo Cordeiro de Farias, s/n , $1^{\circ}$ andar - Petrópolis - 59012-570 - Natal - RN, Brasil. E-mail: aline_schwarz@yahoo.com.br
} 


\section{INTRODUCTION}

Medicinal plants and their preparations have been used to treat several illnesses since the dawn of human history and are one of the foundations for healthcare worldwide (AESGP, 1998; Turolla, 2004; Mendes; Herdeiro; Pimentel, 2010). The observation and experience of primitive man elucidated the therapeutic properties of certain plants and promoted their use from one generation to another (Turolla, 2004).

It is well known that natural products traditionally consumed by a portion of the population may have mutagenic potential. As such, further evaluation and studies are needed in order to confirm this possibility (Freitas, 2007).

The species Phyllanthus niruri Linné, commonly known as "erva-pombinha", "quebra-pedras-de-arvorezinha", "quebra-pedra", "quebra-pedra legítimo" or "quebra-pedra verdadeiro" (names in Portuguese for the herb stonebreaker) (Simões et al., 1986; Garlet, 2000), belongs to the family Euphorbiaceae, which contains approximately three hundred and fifteen genera and eight thousand species (Filho et al., 1996). The herb has a thin straight stalk with many branches, is between 10 and $30 \mathrm{~cm}$ tall (Franco, 1997; Santos, Torres, Leonart, 1987) and can be found in Africa, Asia and the Americas, commonly on coastal plains (Castro-Chaves et al., 2002).

In addition to alkaloids, other compounds including tannins, flavonoids, phenols, triterpenoids, fatty acids, esters of phthalic acid, lignins such as phyllanthin and hypophyllanthin, and vitamin $\mathrm{C}$ have been isolated and characterized in several species of the genus Phyllanthus (Ahmad, Husain, Osman, 1981; Miguel et al., 1996; Quian-Cutrone, 1996; Ueno et al., 1988; Ishimaru et al., 1992; Rajeshkumar et al., 2002; Mahdi et al., 2011; Samali et al., 2012). Studies with P. niruri have found flavonoids such as quercetin and kaempferol (El-Mekkawy et al., 1995), lignin glycosides called phyllanthostatin A, 1 and 2 (Pettit, Schaufelberger, 1988; Pettit et al., 1990), ellagitannins such as geraniin and furosin (Miguel et al., 1996), niruroidine (Quian-Cutrone et al., 1996), lignans as nirtetralin A and B (Wei et al., 2012) among others.

In folk medicine, $P$. niruri is mainly used for urinary tract problems, such as kidney and bladder pain, renal lithiasis, and as a diuretic (Garlet, 2000). Extracts of P. niruri were found to normalize high levels of urinary calcium, reducing the formation of calculus in patients (Nishiura et al., 2004). This suggests it interferes in the first stages of stone formation and may be an alternative in the treatment and/or prevention of urolithiasis and inhibit the formation of calcium oxalate crystals in the urinary tract, preventing renal calculus (Barros et al., 2003; Freitas, Schoe, Boim,
2002). Studies show that the plant promotes relaxation of the ureters which, combined with analgesic action (Santos et al., 1995), facilitates the descent of stones. This generally occurs without pain or bleeding and increases glomerular filtration and the excretion of uric acid (Lorenzi; Matos, 2002), justifying its use for renal lithiasis. The aqueous extract inhibits reverse transcriptase in the human immunodeficiency virus type 1 (HIV-1-RT) (Ogata et al., 1992; El-Mekkawy et al., 1995; Notka, Meier, Wagner, 2003). However, other studies have been conducted in an attempt to prove several other biological activities, such as analgesic action (Miguel et al., 1996; Santos et al., 1995; Santos et al., 2000), anti-tumor activity in different cell lines (Powis, Moore, 1985; Pettit, Schaufelberger, 1988; Pettit et al., 1990; Rajeshkumar, Kuttan, 2000), antioxidant effects in preventing gastric ulcers (Bandyopadhay, Pakrashi, 2000), anti-inflammatory (Ignácio et al., 2001; Kiemer et al., 2003) and anti-malaria activity (Muñoz et al., 2000) and reduced plasma lipid levels in rats (Khanna, Rizvi, Chander, 2002). It also exhibits abortive and purgative action in large doses (Martins et al., 1994). Manjrekar et al. (2008) demonstrated a reduction in carbon tetrachloride-induced hepatotoxic effects in rats treated with an aqueous extract of $P$. niruri.

The use of herbal drugs has long been well known. In order to popularize this knowledge and clarify when and how these drugs should be used to achieve beneficial effects, the National Agency for Sanitary Vigilance (ANVISA) provides notification of herbal drugs through Resolution-RDC No 10 of March 9, 2010 (Brasil, 2010). Standardization for popular use of $P$. niruri as an herbal drug among adults is $3 \mathrm{~g}$ (equivalent to a soup spoon) infused with $150 \mathrm{~mL}$ of water (1 teacup), 2 or 3 times a day. It is recommended for renal lithiasis to help remove small kidney stones but contraindicated for large stones, as well as during pregnancy. Main adverse reactions include diarrhea and hypotension and it should not be used for more than three weeks (Brasil, 2010).

Among genotoxicity tests recommended by international regulatory agencies and government institutions, the in vivo Micronucleus Test (MN) in rat bone marrow is widely accepted and recommended to assess and record new chemical and pharmaceutical products that enter the world market (Krishna, Hayashi, 2000; Ribeiro, 2003; Speit, Zeller, Neuss, 2011). This test is frequently used to detect clastogenic agents (which break chomosomes) and aneugenic agents (which induce aneuploidy or abnormal chromosome segregation due to mitotic spindle dysfunction) (Macgregor et al., 1987; Hayashi et al.; 1994). It was initially developed in mouse bone marrow erythrocytes (Schmid, 1976), but can also be performed on rats (George, Wooton, Gatehouse, 1990). 
In the present study, three different concentrations of dry P. niruri were tested to assess in vivo genotoxic, antigenotoxic and cytotoxic activities in the bone marrow cells of Wistar rats, using MN tests as a parameter. General toxicity was also evaluated after 30-day treatment with aqueous suspension of dry $P$. niruri extract.

\section{MATERIAL AND METHODS}

\section{Materials}

Dry P. niruri extract (lot: 024827, supplier: FLORES E ERVAS) was obtained from a compounding pharmacy in the city of Natal and suspended in water at a concentration of $20 \mathrm{mg} / \mathrm{mL}$. Total tannin and gallic acid content in the lot used was $6.5 \%$ and $0.15 \%$ respectively, in accordance with supplier specifications. Cyclophosphamide was acquired from Sigma Chemical Co., USA; methanol (Merck); Giemsa (Merck); May-Grunwald (Merck); saline solution $(\mathrm{NaCl} 0.9 \%)$.

\section{Animals}

Adult male rats (48) with an initial weight of $280 \mathrm{~g}$ were obtained from the vivarium of the Health Sciences Center at the Federal University of Rio Grande do Norte (UFRN). Individuals were from the same strain of the species Rattus novergicus, family Wistar, and were randomly separated into four groups ( $n=12 /$ group). Over a period of 30 days, three experimental groups received doses of 50,150 and $250 \mathrm{mg} / \mathrm{kg} /$ day of dry $P$. niruri extract, by gavage, suspended in distilled water. The control group received only water, using the same method and time period. Body weight, ration consumption and water intake were monitored during treatment and weight gain was also calculated. Animals were housed in polypropylene cages with metal lids measuring 40 × 50 × $20 \mathrm{~cm}$, for no less than 5 days before being submitted to the different experimental conditions. Individuals were kept in a room at approximately constant temperature $\left(23\right.$ to $\left.26^{\circ} \mathrm{C}\right)$ in a 12 hour light/dark cycle, where lights were turned on at $6.00 \mathrm{~h}$. Water and feed (Labina ${ }^{\circledR}$ - Purina) were offered $a d$ libitum throughout the experimental process. The research project was approved by the Ethics Committee on Animal Use at the Federal University of Rio Grande do Norte (CEUA - UFRN) under protocol number 024/2010. The methodology used was in accordance with guidelines of the Brazilian Animal Experimentation College (COBEA) and standards described in Law $\mathrm{n}^{\circ} 11.794 / 2008$.

Doses adopted were calculated considering the recommended dose for use in human adults to treat renal lithiasis; around $130 \mathrm{mg} / \mathrm{kg} /$ day (Brasil, 2010). Thus, a smaller, a similar and a larger dose were used to evaluate general toxicity.

\section{Genotoxicity assessment by the MN test in mouse bone marrow}

At the end of the 30-day treatment, animals from experimental and control groups were subdivided into smaller groups of six animals each. One of the new smaller groups for each treatment received $0.9 \%$ saline solution i.p. (at a volume of $1.0 \mathrm{~mL}$ ) and the remaining groups received $50 \mathrm{mg} / \mathrm{kg}$ i.p of cyclophosphamide.

After 24 hours of the above treatments, animals were euthanized with sodium thiopental (50mg/kg i.p.) and the femur was aseptically exteriorized and removed. The Schmid method (1976) was used to obtain bone marrow cells for the MN frequency study, modified by Zambrano, Targa and Rabello-Gay (1982). The far end of the proximal femur was cut to expose the spinal canal. Next, a syringe needle previously filled with $1.0 \mathrm{~mL}$ of $0.9 \%$ sterile saline solution was inserted firmly into the opening, injecting the serum and extracting the cells from the femoral cavity of each animal. Cells were place in $15 \mathrm{~mL}$ conical centrifuge tubes.

\section{Slide preparation for $\mathrm{MN}$ research}

Centrifuge tubes containing the bone marrow cells were centrifuged for 5 minutes at $1000 \mathrm{rpm}$, discarding the supernatant. From the resulting suspension, a small drop was transferred to a glass slide for distension. Two smears were performed per animal and slides were kept at room temperature for drying. May-Grunwald-Giemsa stain was used, modified by Rosenfeld. Staining allowed for differentiation between polychromatic (PCE) and normochromatic erythrocytes (NCE). Genotoxic and antigenotoxic activity was assessed on an optical microscope with a 100x objective lens (zigzag orientation), using the frequency of micronucleated polychromatic erythrocytes (MNPCE) in 1000 polychromatic erythrocytes, for each animal. We also determined the polychromatic erythrocyte count in 200 total erythrocytes (PCE + NCE) by the PCE/ NCE ratio in order to confirm the presence of cytotoxicity.

\section{Statistical analysis}

Data were assessed with the analysis of variance (ANOVA) method and the Tukey-Kramer test, when necessary. Data were considered statistically significant for all groups when $P<0.05$. 


\section{RESULTS}

Statistical analysis revealed no changes in body weight (Table 1) and food consumption (Figure 1) for animals treated with $P$. niruri when compared with controls. However, body weight gain was lower in the group treated with a dose of $150 \mathrm{mg} / \mathrm{kg} /$ day from the first to the sixth day of treatment $[\mathrm{F}(3 / 44)=3.790 ; \mathrm{p}<0.05]$ and over the entire treatment period $[\mathrm{F}(3 / 44)=2.961 ; \mathrm{p}<0.05]$ (Figure 2 ).

Only isolated alterations in water intake were detected (Figure 3). Statistical analysis revealed reduced water consumption in groups treated with doses of $50 \mathrm{mg} / \mathrm{kg} /$ day

TABLE I - Body weight (g) of male rats treated or not (control) with different doses of dry P. niruri extract (50, $150 \mathrm{or} 250 \mathrm{mg} / \mathrm{kg} / \mathrm{day}$; p.o.) for 31 days. Means and the respective standard errors are shown ( $n=12 /$ group)

\begin{tabular}{lcccc}
\hline Day of treatment & Control & P. niruri $50 \mathrm{mg} / \mathrm{kg} /$ day & P. niruri $150 \mathrm{mg} / \mathrm{kg} /$ day & P. niruri $250 \mathrm{mg} / \mathrm{kg} / \mathrm{day}$ \\
\hline 1 & $269.42 \pm 13.02$ & $291.00 \pm 10.36$ & $278.75 \pm 12.36$ & $279.75 \pm 9.34$ \\
3 & $277.58 \pm 10.55$ & $293.42 \pm 10.14$ & $291.92 \pm 17.47$ & $279.75 \pm 10.03$ \\
5 & $281.08 \pm 10.22$ & $293.92 \pm 10.15$ & $277.50 \pm 12.44$ & $283.83 \pm 10.13$ \\
7 & $283.92 \pm 9.03$ & $286.17 \pm 7.32$ & $279.00 \pm 12.60$ & $286.83 \pm 9.28$ \\
9 & $288.08 \pm 9.07$ & $294.92 \pm 9.85$ & $280.92 \pm 12.90$ & $285.92 \pm 9.67$ \\
11 & $290.17 \pm 8.84$ & $296.08 \pm 9.92$ & $281,33 \pm 12.43$ & $289.50 \pm 8.97$ \\
13 & $290.50 \pm 9.04$ & $298.83 \pm 10.08$ & $280.83 \pm 12.73$ & $290.50 \pm 9.26$ \\
15 & $293.92 \pm 8.13$ & $297.92 \pm 10.29$ & $281.17 \pm 12.49$ & $291.67 \pm 9.28$ \\
17 & $292.58 \pm 7.87$ & $300.75 \pm 10.72$ & $283.83 \pm 12.70$ & $292.83 \pm 9.21$ \\
19 & $296.08 \pm 8.35$ & $302.58 \pm 10.69$ & $284.83 \pm 12.53$ & $294.17 \pm 9.87$ \\
21 & $298.67 \pm 8.27$ & $305.00 \pm 10.39$ & $288.50 \pm 12.89$ & $295.75 \pm 9.78$ \\
23 & $299.58 \pm 7.31$ & $306.50 \pm 10.40$ & $288.58 \pm 12.77$ & $298.00 \pm 9.38$ \\
25 & $293.83 \pm 10.72$ & $308.50 \pm 10.69$ & $288.92 \pm 13.10$ & $300.25 \pm 9.45$ \\
27 & $303.92 \pm 7.73$ & $310.17 \pm 10.60$ & $291.42 \pm 12.85$ & $300.25 \pm 9.39$ \\
29 & $304.25 \pm 7.37$ & $310.42 \pm 10.64$ & $292.00 \pm 12.81$ & $301.75 \pm 9.85$ \\
31 & $305.00 \pm 7.13$ & $313.92 \pm 10.69$ & $294.58 \pm 12.97$ & $303.50 \pm 9.68$ \\
\hline P & & & &
\end{tabular}

$\mathrm{P}>0.05 ;$ ANOVA

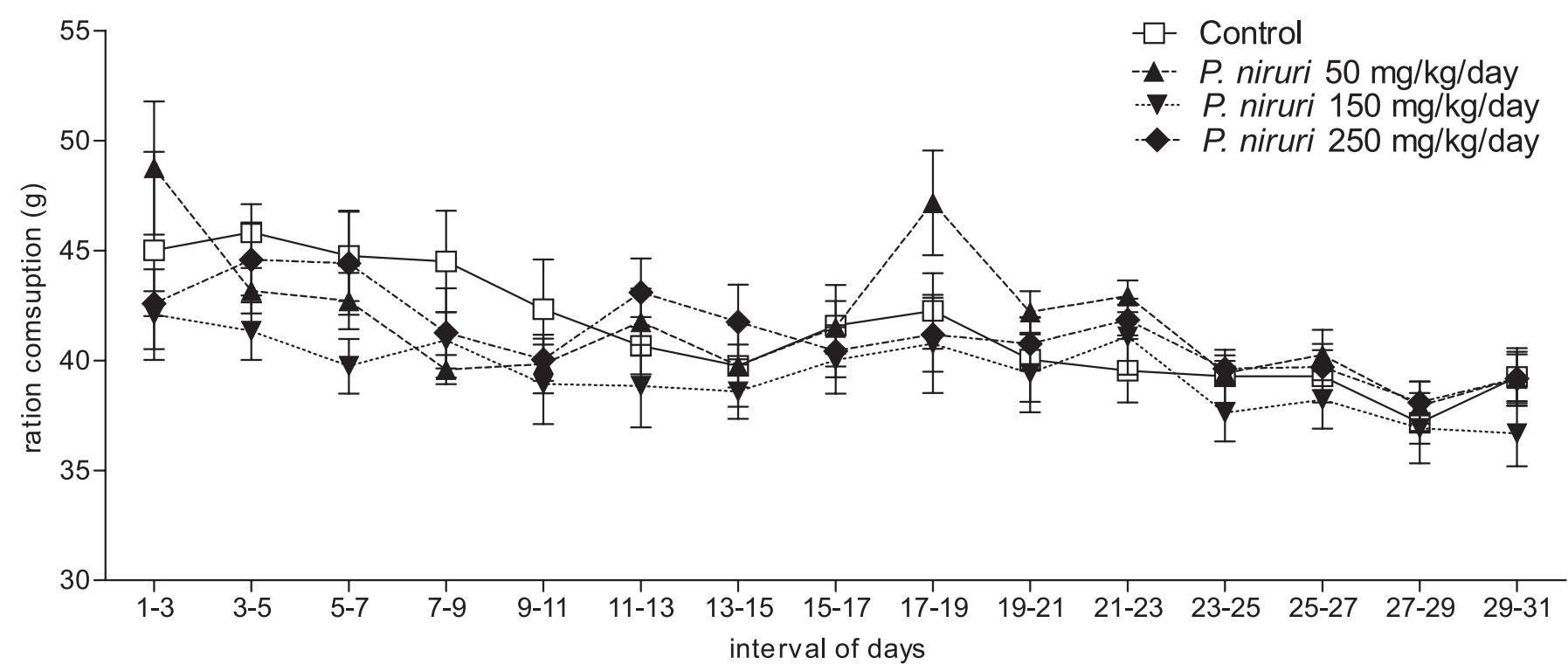

FIGURE 1 - Feed intake (g) of male rats treated or not (control) with different doses of dry P. niruri extract (50, $150 \mathrm{or} 250 \mathrm{mg} / \mathrm{kg} / \mathrm{day}$; p.o.) for 31 days. The above values represent the mean and respective standard error for each group ( $>0.05$; ANOVA). 


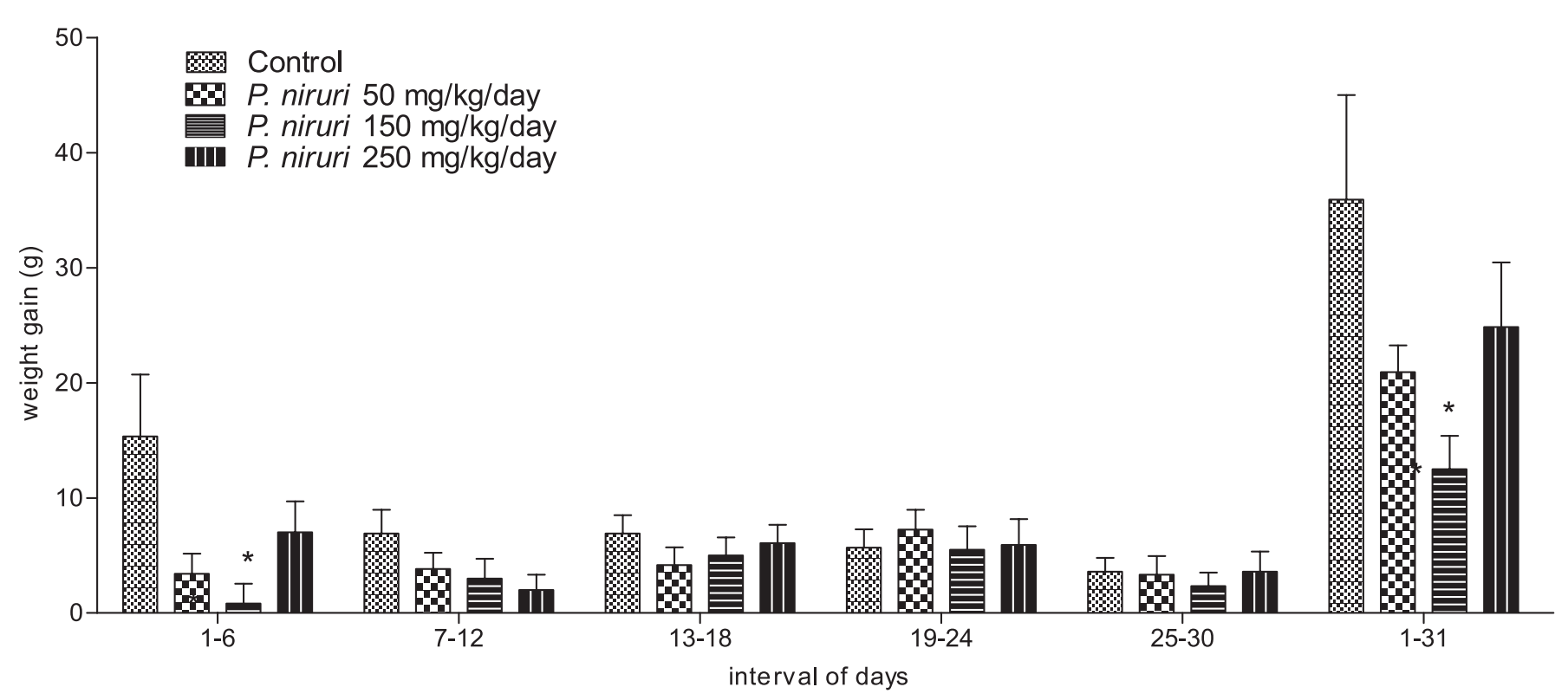

FIGURE 2 - Weight gain (g) among male rats treated or not (control) with different doses of dry P. niruri extract (50, 150 or 250 $\mathrm{mg} / \mathrm{kg} / \mathrm{day}$; p.o.) for 31 days. The above values represent the mean and respective standard error for each group. (ANOVA, TukeyKramer Test, ${ }^{*} \mathrm{p}<0.05$ in relation to the control group).

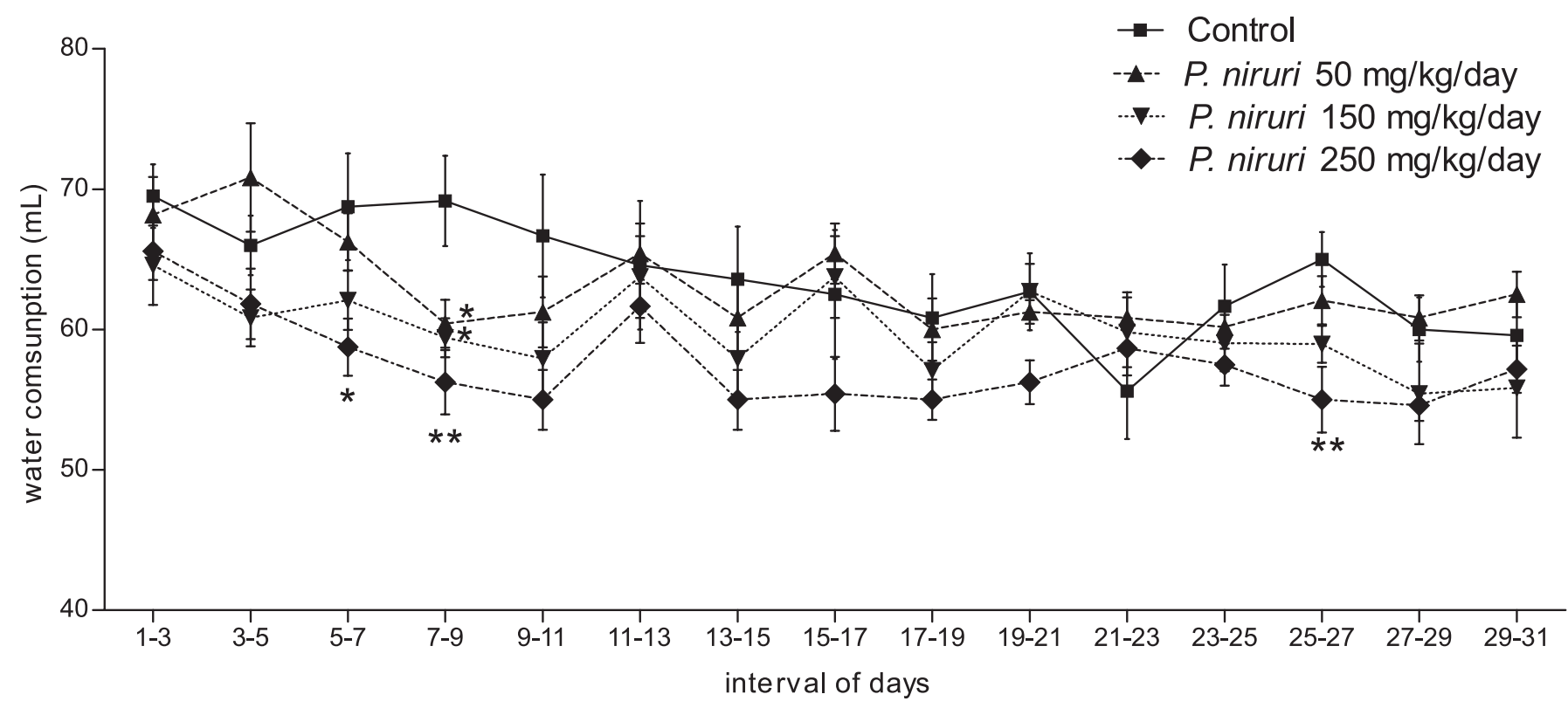

FIGURE 3 - Water intake $(\mathrm{ml})$ for male rats treated or not (control) with different doses of dried P. niruri extract (50, 150 or $250 \mathrm{mg} / \mathrm{kg} /$ day; p.o.) for 31 days. The above values represent the mean and respective standard error for each group. ANOVA, Tukey-Kramer test, ${ }^{*} \mathrm{p}<0.05,{ }^{* *} \mathrm{p}<0.01$ in relation to the control.

$[\mathrm{F}(3 / 44)=5.976 ; \mathrm{p}<0.05]$ and $150 \mathrm{mg} / \mathrm{kg} /$ day $[\mathrm{F}(3 / 44)=$ $5.976 ; \mathrm{p}<0.05$ ] during day 9 of treatment and by the group treated with the larger dose on day $7[\mathrm{~F}(3 / 44)=2.884$; $\mathrm{p}<0.05], 9[\mathrm{~F}(3 / 44)=5.976 ; \mathrm{p}<0.01]$ and $27[\mathrm{~F}(3 / 44)=$ $5.285 ; \mathrm{p}<0.01]$.

When evaluating the mutagenicity of dry $P$. niruri extract, the animals treated only with this extract exhibited a statistically lower MN frequency in relation to the positive control group $[\mathrm{F}(7 / 40)=24.762 ; \mathrm{p}<0.001]$. Groups treated with $P$. niruri and cyclophosphamide showed an increase in $\mathrm{MN}$ frequency in relation to negative controls $[\mathrm{F}(7 / 40)=24.762 ; \mathrm{p}<0.001]$ and a decrease in this parameter in comparison to groups treated only with $P$. niruri $[\mathrm{F}(7 / 40)=24.762 ; \mathrm{p}<0.001]$. This behavior is similar to 
groups treated only with cyclophosphamide, which display an increase in MNPCE frequency in relation to negative controls $[F(7 / 40)=24.762 ; p<0.001]$ (Figure 4).

Cytotoxicity evaluation of bone marrow erythrocytes showed animals treated with the extract exhibited a statistically higher PCE/NCE ratio when compared with positive controls (Figure 5). This is similar to the negative control group, indicating a lack of cytotoxicity in the extract.

\section{DISCUSSION}

Toxicological assessment of plant extracts is a mean of investigating possible collateral effects and establishing their safe use by the population.

According to Barros et al. (2005), there is great concern about the safe use of plant extracts. Freitas (2007) underscores that natural products traditionally consumed by the population need further study, since they may

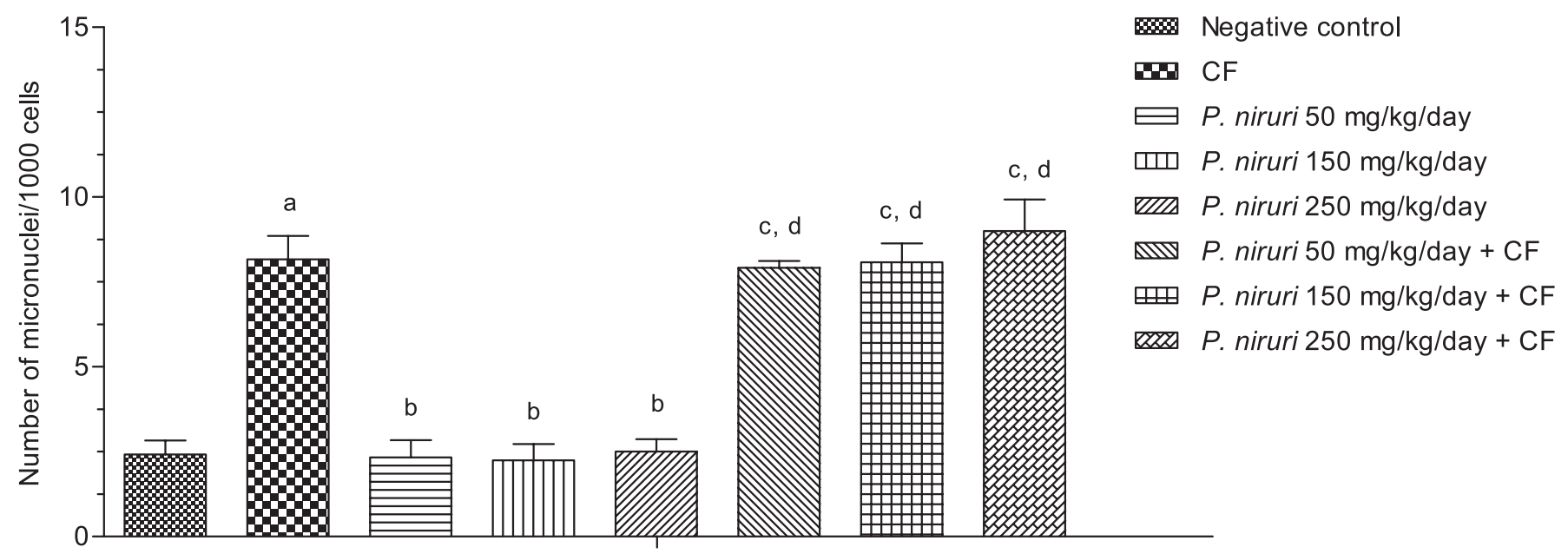

FIGURE 4 - Evaluation of micronuclei frequency in polychromatic erythrocytes (PCE) in the bone marrow of rats (n=6/group) exposed to different doses of dry P. niruri extract $(50,150 \mathrm{or} 250 \mathrm{mg} / \mathrm{kg} /$ day; p.o.). The positive control group received a single dose of cyclophosphamide (CF) $\left(50 \mathrm{mg} / \mathrm{kg}\right.$; i.p.). The above values represent the mean and standard error for each group ${ }^{\mathrm{a}, \mathrm{b}, \mathrm{c}, \mathrm{d}}$ ( $<0.001$, ANOVA followed by the Tukey-Kramer test). (a) positive control $v s$ negative control; (b) P. niruri vs positive control; (c) P. niruri + cyclophosphamide $v$ s negative control; (d) P. niruri + cyclophosphamide $v$ s P. niruri.

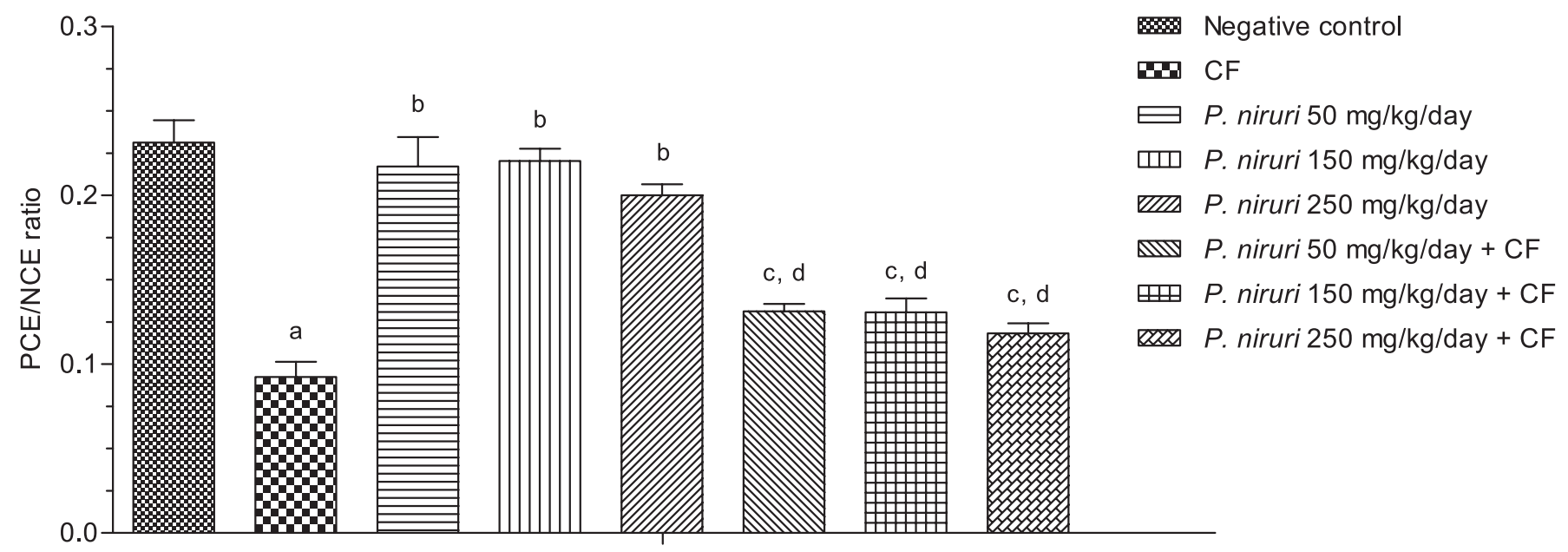

FIGURE 5 - Evaluation of the polychromatic/normochromatic ratio (PCE/NCE) in the bone marrow of rats (n=6/goup) exposed to different doses of dry P. niruri extract (50,150 or $250 \mathrm{mg} / \mathrm{kg} /$ day; p.o.). The positive control group received a single dose of cyclophosphamide (CF) $\left(50 \mathrm{mg} / \mathrm{kg}\right.$; i.p.). The above values represent the mean and standard error for each group ${ }^{\mathrm{a}, \mathrm{b}, \mathrm{c}, \mathrm{d}}(\mathrm{p}<0.001$, ANOVA followed by the Tukey-Kramer test). (a) positive control $v$ s negative control; (b) P. niruri vs positive control; (c) P. niruri + cyclophosphamide $v s$ negative control; (d) P. niruri + cyclophosphamide vs P. niruri. 
be mutagenic. In order to ensure the quality and safety of phytomedicines, the Brazilian National Agency of Sanitary Vigilance (ANVISA) published resolution no. 17 (Brazil, 2000) on 24 February 2000, decreed that they must be submitted to preclinical and clinical toxicological trials.

In this study general bone marrow toxicity, genotoxicity and cytotoxicity were assessed, using the micronucleus test in rats fed dry $P$. niruri $\mathrm{L}$ extract.

Nwanjo (2006) evaluated acute toxicity of aqueous extract of $P$. niruri leaves in Wistar rats after treatment with doses between 250 and $1,500 \mathrm{mg} / \mathrm{kg}$ of body weight (i.p.), obtaining a DL50 of $516.2 \mathrm{mg} / \mathrm{kg}$. Asare et al. (2012) observed, in a study developed with adult Sprague Dawley rats, that an ethanolic extract obtained from $P$. niruri was not acutely toxic at $3,000 \mathrm{mg} / \mathrm{kg}$. Studies in mice revealed low toxicity in the aqueous extract of $P$. niruri, intraperitoneally administered at a dose of $1.8 \mathrm{mg} / \mathrm{kg} /$ day, showing no body weight loss after three days of treatment and a slight weight gain after seven days of treatment (Venkateswaran, Millman, Blumberg, 1987). Tona et al. (2001) demonstrated that aqueous and ethanol extract of $P$. niruri orally administered to mice at a dose of $500 \mathrm{mg} / \mathrm{kg}$ of body weight, once a week, for 4 weeks, caused no toxic effects or deaths. In our study, we observed a slight reduction of water intake (Figure 3) in rats treated with doses of 150 and $250 \mathrm{mg} / \mathrm{kg} / \mathrm{day}$ of $P$. niruri when compared to the control group. However, we found no alterations in body weight (Table I), in body weight gain (Figure 1) or food consumption (Figure 2) in animals treated with $P$. niruri extract, corroborating the data of the abovementioned studies. These data are insufficient to confirm or not the toxicity of chemical substances; however, basic parameters allow us to suggest or not their toxicity. Several other tests, such as the serum and/or plasma investigation of biochemical parameters, as well as histopathological, genotoxic, mutagenic and behavioral studies, are important for a more consistent determination of chemical compound toxicity. A study recently developed (Asare et al., 2012) observed that an ethanolic extract obtained from $P$. niruri whole plant was not toxic to adult rats treated during 90 days with 30 and $300 \mathrm{mg} / \mathrm{kg}$. Hematological, biochemical or histopathological alterations were not observed in rats treated with the higher dose. However, the lower dose promoted lymphocyte reduction and drastic reduction was observed in most liver function test parameters (bilirubin, AST and ALT), suggesting some degree of hepatoprotection. Otherwise, the authors conclude that the $P$. niruri whole plant ethanolic extract is generally non-toxic. This data corroborates with the findings in the actual study where the three doses $(50,150$ and $250 \mathrm{mg} / \mathrm{kg})$ of the aqueous extract obtained from $P$. niruri dry leaves were sufficient to promote mild toxicity to rats treated during 30 days.

Antioxidant activity of $P$. niruri was reported by Harish and Shivanandappa (2006). Aqueous and methanol extracts at a dose of $100 \mathrm{mg} / \mathrm{kg}$ of body weight were cited as potent inhibitors of $\mathrm{Fe}^{2+}$ and ascorbate-induced microsomal lipid peroxidation; inhibitors of superoxide radical formation; and DPPH radical scavengers in in vitro studies. According to the authors, this antioxidant potential was responsible for inhibiting carbon tetrachloride-induced lipid peroxidation in rat livers. Shyamasundar et al. (1985) demonstrated that chemical components such as phyllanthin and hypophyllanthin could protect against carbon tetrachloride $\left(\mathrm{CCL}_{4}\right)$ cytotoxicity in primary cultures of isolated hepatocytes.

The cytotoxicity of a substance can be assessed by the PCE/NCE ratio. According to Mavournin et al. (1990), the ratio between PCE and NCE frequency decreases when replacement of PCEs originating in erythroblasts is lowered. Results show that there was no statistically significant decrease in the PCE/NCE ratio in the groups treated only with dry extract of $P$. niruri compared to negative control in all doses $(\mathrm{p}>0.05)$. The PCE/NCE ratio obtained for each dose of extract was similar to that found for the negative control group and quite different from that observed in the positive control group (Figure 5). Moreover, dry extract demonstrated no protective action against cyclophosphamide-induced cytotoxicity in rat bone and the PCE/NCE ratio fell in groups treated with $P$. niruri and cyclophosphamide. In the present study dry extract of $P$. niruri exhibited no cytotoxic activity under the experimental conditions used.

MNs appear in daughter cells, due to damage induced in parental cells (Ribeiro, 2003). The two basic phenomena that result in $\mathrm{MN}$ formation in mitotic cells are chromosomal breakage and nondisjunction of the mitotic apparatus. MNs are formed from acentric or chromatid chromosomal fragments that are delayed in the anaphase and are not included in daughter cell nuclei in the telophase (Ford et al., 1988; Lindholm et al., 1991; Ford, Corel, 1992; Catalán, Falck, Norppa, 1973; Falck, Catalán, Norppa, 2002).

Formation of MNs in dividing cells is the result of chromosome breakage due to loss of repair or no repair of DNA lesions, or of poor segregation owing to nondisjunction in the mitotic apparatus. These events can be induced by oxidative stress, exposure to clastogenic or aneugenic agents, genetic defects in repair genes and/or cell cycle control, as well as deficiency in nutrients required as cofactors in DNA metabolism and chromosome segregation (Kimura et al., 2004; Umegaki, Fenech, 2000; Rajagopa- 
lan et al., 2004; Macgregor, 2005; Fenech et al., 2005). All events causing MN formation, such as chromosomal rearrangements, gene expression changes or aneuploidy, are associated with chromosome instability generally observed in cancer (Rajagopalan et al., 2004; Fenech, 2002; Ames, Wakimoto, 2002).

As expected, our results corroborate data from the literature confirming the genotoxic effect of cyclophosphamide expressed by the increased frequency of micronuclei. Cyclophoshamide is an atineoplastic agent with alkylating properties, which indiscriminately complexes with DNA among normal and cancerous cells and is inactive until it is metabolized in the liver by mixed function oxidases of the cytochrome P-450 (Valadares, Castro, Cunha, 2007; Rang et al., 2003). The acute toxicity of cyclophosphamide is primarily associated with its genotoxicity (Krishna; Hayashi, 2000). In somatic cells, it provokes gene mutations, chromosomal aberrations, micronuclei and exchanges of sister chromatids in a variety of cell cultures with and without the presence of metabolic activation (Monteith, Vanstone, 1995; Elhajouji et al., 1994; Madle et al., 1986). Cyclophosphamide also damages chromosomes and micronuclei in the hematopoietic system of rats, mice and Chinese hamsters by producing highly reactive carbon ions (Moore et al., 1995).

Other species of the genus Phyllanthus, as P. amarus demonstrated antimutagenic properties. Sripanidkulchai et al. (2002) demonstrated that $P$. amarus protects against mutagenic effects of 2-aminofluorene, 2-aminoanthracene, 4-nitroquinoline 1-oxide, $N$-ethyl- $N$-nitro- $N$-nitrosoguanidine, 2-nitrofluorene and sodium azide in bacteria testing, as well as antagonize DNA damage caused by dimethylnitrosamine in hamster livers. Kumar and Kuttan (2004) reported that orally-administered aqueous extract of $P$. amarus offers radioprotection in rats by suppressing the formation of reactive oxygen species (ROS). This detoxifies species induced by radiation, increasing restoration and repair processes, accelerating hematopoietic recovery and possibly regulating the activity of response genes. The same authors (2005) also demonstrated the chemoprotective activity of $75 \% P$. amarus methanolic extract induced by cyclophosphamide in mice. The extract significantly lowered myelosuppression and improved bone marrow cellularity. It also increased glutathione (GSH) and cellular glutathione-S-transferase (GST), reducing the toxic effects of cyclophosphamide metabolites in the cells. Asare et al. (2012) observed that an ethanolic extract obtained from $P$. niruri was not able to promote micronucleus at PCE bone marrow cells of adult rats treated with a single dose of 30 or $300 \mathrm{mg} / \mathrm{kg}$. In this study, $N$-ethyl- $n$-nitrosourea, was employed as positive control. After $48 \mathrm{~h}$ of treatment the animals were killed and bone marrow collected for evaluation of genotoxic and cytotoxic activities. The authors revealed that the extract adopted was not genotoxic or cytotoxic, corroborating with the data obtained in the actual study.

In all groups treated only with $P$. niruri extract, PCEMN frequency was similar to the spontaneous PCEMN rate of 3 micronuclei per 1000 PCEs (RabelloGay, 1991), found in the negative control group. These data suggest the extract does not exhibit mutagenic activity. Furthermore, our research with dry $P$. niruri extract in doses of 50,150 and $250 \mathrm{mg} / \mathrm{kg}$ of body weight, with subchronic oral administration, different as observed in the studies mentioned above with $P$. amarus (Sripanidkulchai et al., 2002; Kumar, Kuttan, 2004; Kumar, Kuttan, 2005) showed no protective activity in bone marrow cells against damage caused by cyclophosphamide. This was evidenced by the similar PCEMN frequency between the groups treated with the extract + cyclophosphamide and the positive control group. The different animal species employed in our study (rats) and the above mentioned studies (hamster and mice) as well as the plant species and the doses and treatment periods may explain the absence of effects against damage caused by cyclophosphamide.

\section{CONCLUSIONS}

The data revealed here suggest that subchronic oral administration of dry P. niruri extract to Wistar rats in the three different doses shows low toxicity and exhibits no genotoxic or cytotoxic potential in bone marrow cells, or chemoprotective properties against damage caused by cyclophosphamide. This favors the medicinal use of the plant in doses recommended for humans.

\section{ACKNOWLEDGEMENTS}

This study was undertaken with the support of the Vivarium at the Health Sciences Center of UFRN, which provided the animals, food and space required for accommodating the animals during the treatment period. We would like to express our thanks to UFRN for making this research possible. Special thanks to Ivanise Marina Moretti Rebecchi by technical support during micronucleus visualization.

\section{REFERENCES}

AHMAD, M.U.; HUSAIN, S.K.; OSMAN, S.M. Ricinoleic acid in Phyllanthus niruri seed oil. JAOCS, v.58, p.673674, 1981. 
AMES, B. N.; WAKIMOTO, P. Are vitamin and mineral deficiencies a major cancer risk? Nat. Rev. Cancer, v.2, p.694-704, 2002.

AMORIM, M. F. D.; DINIZ, M. F. F. M.; ARAÚJO, M.S. T.; PITA, J. C. L. R.; DANTAS, J. G.; RAMALHO, J. A.; XAVIER, A. L.; PALOMARO, T. V.; JÚNIOR, N. L. B. The controvertible role of kava (Piper methysticum G. Foster) an anxiolytic herb, on toxic hepatitis. Rev. Bras. Farmacogn., v.17, p.448-454, 2007.

ASARE, G. A.; BUGYEI, K.; SITTIE, A.; YAHAYA, E.S.; GYAN, B.; ADJEI, S.; ADDO, P.; WIREDU1, E.K.; ADJEI1, D.N.; NYARKO, A. K. Genotoxicity, cytotoxicity and toxicological evaluation of whole plant extracts of the medicinal plant Phyllanthus niruri (Phyllanthaceae). Gen. Mol. Res., v. 11, n. 1, p. 100-111, 2012.

\section{ASSOCIATION OF THE EUROPEAN SELF MEDICATION} INDUSTRY. AESGP. Herbal medicinal products in the European Union. In The Association of the European SelfMedication Industry Study carried out on behalf of the European Commission, 1990. p.1-104.

BANDYOPADHAY, S.K.; PAKRASHI, S.C.; PAKRASHIA. The role of antioxidant activity of Phyllanthus emblica fruits on prevention from indomethacin induced gastric ulcer. J. Ethnopharmacol., v.70, p.171-176, 2000.

BARROS, M. E.; SCHOR, N.; BOIM, M. A. Effects of an aqueous extract from Phyllantus niruri on calcium oxalate crystallization in vitro. Urol. Res., v.30, p.374-379, 2003.

BARROS, S.; ROPKE, C. D.; SAWADA, T. C. H.; SILVA, V. V.; PEREIRA, S. M. M.; BARROS, S. B. M. Assessment of acute and subchronic oral toxicity of ethanolic extract of Pothomorphe umbellate L. Miq. (Pariparoba). Braz. J. Pharm. Sci., v.41, p.53-61, 2005.

BRASIL. Ministério da Saúde. Agência Nacional de Vigilância Sanitária. Resolução RDC n 10, de 09 de março de 2010. Dispõe sobre a notificação de drogas vegetais junto à Agência Nacional de Vigilância Sanitária (ANVISA) e dá outras providências. Diário Oficial da União, Brasília (DF), 10 de mar. 2010. Available at: <http://www.anvisa.gov.br $>$. Accessed on: 05 may 2010.
BRASIL. Ministério da Saúde. Agência Nacional de Vigilância Sanitária. Resolução RDC no 17, de 24 de fevereiro de 2000. Dispõe sobre o registro de medicamentos fitoterápicos. Diário Oficial da União, Brasília (DF), 25 de fev. 2000. Available at: <http://www.anvisa.gov.br>. Accessed on: 05 may 2010.

BROWN, T.A. Genética: um enfoque molecular. 3.ed. Rio de Janeiro: Guanabara Koogan, 1999. 336 p.

CAPASSO, R.; IZZO, A.A.; PINTO, L.; BIFULCO, T.; VITOBELLO, C.; MASCOLO, N. Phytotherapy and quality of herbal medicines. Fitoterapia, v.71, p.S58-S65, 2000 .

CARRANO, A.; HEDDLE, J. A. The fate of chromosome aberrations. J. Theoret. Biol., v.38, p.289-304, 1973.

CASTRO-CHAVES, C.; CUNHA, A.M.F.; CRUZ, G.M.C.; OLIVEIRA, D.V.O. O Phyllanthus niruri L. induz caliurese dissociada da diurese e da natriurese em ratos acordados. Rev. Bras. Farmacogn., v.12, p.2-4, 2002.

CATALÁN, J.; FALCK, G.C.M.; NORPPA, H. The X chromosome aberrations. J. Theoret. Biol., v.38, p.289304, 1973.

COELHO, H.L. Farmacovigilância: um instrumento necessário. Cad. Saúde Pública, v.14, p.871-875, 1998.

CORDEIRO, C.H.G.; CHUNG, M.C.; SACRAMENTO, L.V.S. Interações medicamentosas de fitoterápicos e fármacos: Hypericum perforatum e Piper methysticum. Rev. Bras. Farmacogn., v.15, p.272-278, 2005

CORDELL, G.A. Changing strategies in natural products chemistry. Phytochemistry, v.40, p.1585-1612, 1995.

DELMANTO, R.D.M.; EIRA, A.F.; SALVADORI, D.M.F.; RIBEIRO, L.R. Antimutagenic effect of Agaricus blazei Murril mushroom on the genotoxicity induced by cyclophosphamide. Mutat. Res., v.496, p.15-21, 2001.

ELHAJOUJI, A.; SANTOS, A.P.; VAN HUMMELEN, P.Y.; KIRSCH-VOLDERS, M. Metabolic differences between whole blood and isolate lymphocyte culture for Micronuleus $(\mathrm{MN})$ induction for cyclophosphamide and benzo- $\alpha$-pyrene. Mutagenesis, v.9, p.307-313, 1994. 
EL-MEKKAWY, S.; MESELHY, M.R.; KUSUMOTO, I.T.; KADOTA, S.; HATTORI, M.; NAMBA, T. Inhibitory effects of Egyptian folk medicines on human immunodeficiency virus (HIV) reverse transcriptase. Chem. Pharm. Bull., v.43, p.641-648, 1995.

ERDTMANN, B. A genotoxicidade nossa de todos os dias. In: SILVA, J.; ERDTMANN, B.; HENRIQUES, J.A.P. Genética toxicológica. Porto Alegre: Ed. Alcance, 2003. cap.1, p.21-48.

FAIRBAIRN, D.W.; OLIVE, P.L.; O’NEIL, K.L. The comet assay: a comprehensive review. Mutat. Res., Amsterdam, v.339, p.37-59, 1995.

FALCK, G.C.M.; CATALÁN, J.; NORPPA, H. Nature of anaphase laggards and micronucleus in female cytokineisblocked lymphocytes. Mutagenesis, v.17, p.111-117, 2002.

FENECH, M. The in vitro micronucleus technique. Mutat. Res., v.455, p.81-95, 2000.

FENECH, M. Biomarkers of genetic damage for cancer epidemiology. Toxicology, v.181, p.411-416, 2002.

FENECH, M.; BAGHURST, L.W.; TURNER, J.; RECORD, S.; CEPPI, M.; BONASSI, S. Low intake of pantothenic acid, biotin and riboflavin are significantly associated with increased genome instability - results from a dietary intake and micronucleus index survey in South Australia. Carcinogenesis, v.26, p.991-999, 2005.

FILHO, V.C.; SANTOS, A.R.S.; CAMPOS, R.P.; MIGUEL, O.G.; YUNES, R.A.; FERRARI, F.; MESSANA, I.; CALIXTO, J.B. Chemical and pharmacological studies of Phyllanthus caroliniensis in mice. J. Pharm. Pharmacol., v.48, p.1231-1236, 1996.

FORD, J.H.; CORRELL, A.T. Chromosome errors at mitotic anaphase. Genome, v.35, p.702-705, 1992.

FORD, J.H.; SCHULTZ, C.J.; CORRELL, A.T. Chromossome elimination in micronuclei: a common cause of hipoploidy. Am. J. Hum. Genet., v.42, p.733-740, 1988.

FRANCO, L.L. As sensacionais 50 plantas medicinais campeãs de poder curativo. São Paulo: Santa Mônica, 1997. p.203204.
FREITAS, A.M.; SCHOR, N.; BOIM, M.A. The effects of Phyllanthus niruri on urinary inhibitors of calcium oxalate crystallization and other factors associated with renal stone formation. B. J. U. Intern., v.89, p.829-834, 2002.

FREITAS, P.S. Investigação do potencial mutagênico do extrato de frutos de Vaccinium corymbosum (mirtilo) em células do sangue periférico de camundongos swiss in vivo. 2007. Alfenas, 2007. 72 f. Dissertation of Master degree. Postgraduation in Genetics. José do Rosário Vellano University.

GARLET, T.M.B. Levantamento das plantas medicinais utilizadas no município de Cruz Alta, RS, Brasil. Porto Alegre, 2000. 220 f. Dissertation of Master degree. Postgraduation in Botanics. Federal University of Rio Grande do Sul.

GATEHOUSE, D.G.; WILCOX, P.; FORSTER, R.; ROWLAND, I.R.; CALLANDER, R.D. Bacterial mutation assay. In: KIRKLAND, D.J. Basic mutagenics tests: UKEMS recommended procedures. New York: Cambridge University Press, 1990. cap.2, p.13-61.

GEORGE, E.; WOOTON, A.K.; GATEhOUSE, D.G. Micronucleus induction by azobenzene and 1,2-dibromo3-chloropropane in rat: Evaluation of a triple-dose protocol. Mutat. Res., Amsterdam, v.324, n.3-4, p.129-134, 1990.

HARI KUMAR, K. B.; KUTTAN, R. Protective effect of an extract of Phyllanthus amarus against radiation induced damage in mice. J. Radiat. Res., v.45, p.133-139, 2004.

HARI KUMAR, K.B.; KUTTAN, R. Chemoprotective activity of an extract of Phyllanthus amarus against cyclophosphamide induced toxicity in mice. Phytomedicine, v.12, n.6-7, p. 494-500, 2005.

HARISH, R.; SHIVANANDAPPA, T. Antioxidant activity and hepatoprotective potential of Phyllanthus niruri. Food Chem., v.95, n.2, p.180-185, 2006.

HAYASHI, M.; TICE, R.R.; MACGREGOR, J.T.; ANDERSON, D.; BLAKEY, D.H.; KIRSCH-VOLDERS, M.; OLESON JÚNIOR, F.B.; PACCHIEROTTI, F.; ROMAGNA, F.; SHIMADA, H.; SUTOU, S.; VANNIER, B. In vivo rodent erythrocyte micronucleus assay. Mutat. Res., v.312, p.293304. 1994.

HEDDLE, J.A. A rapid in vivo test for chromosomal damage. Mutat. Res., v.18, n.2, p. 187-190, 1973. 
HEDDLE, J.A.; CARRANO, A.V. The DNA content of micronuclei induced in mouse bone marrow by $\mathrm{X}$-irradiation: evidence that micronuclei arise from acentric chromosomal fragments. Mutat. Res., v.44, p.63-69, 1977.

HEDDLE, J.A.; SALAMONE, M.F. The micronucleus assay in vivo. In: STICH, H.; SAN, R. H. C. Proceedings of the International Workshop on Short-Term Tests for Chemical Carcinogens. New York: Springer-Verlag, 1981. p.243-249.

IGNÁCIO, S.R.N.; FERREIRA, J.L.P.; ALMEIDA, M.B.; KUBELKA, C.F. Nitric oxide production by murine peritoneal macrophages in vitro and in vivo treated with Phyllanthus tenellus extracts. J. Ethnopharmacol., v.74, p.181-187, 2001.

ISHIMARU, K.; YOSHIMATSU, K.; YAMAKAWA, T.; KAMADA, H.; SHIMOMURA, K. Phenolic constituents in tissue cultures of Phyllanthus niruri. Phytochemistry, v.31, p.2015-2018, 1992.

KHANNA, A.K.; RIZVI, F.; CHANDER, R. Lipid lowering activity of Phyllanthus niruri in hyperlipemic rats. $J$. Ethnopharmacol., v.82, n.11, p.19-22, 2002.

KIEMER, A.K.; HARTUNG, T.; HUBER, C.; VOLLMAR, A.M. Phyllanthus amarus has anti-inflammatory potential by inhibition of iNOX, COX-2, and cytokines via the NF- $\kappa$ B pathway. J. Hepatol., v.38, p.289-297, 2003.

KIMURA, M.; UMEGAKI, K.; HIGUCHI, M.; THOMAS, P.; FENECH, M. Methylenetetrehydrofolate reductase C6\&T polymorphism, folic acid and riboflavin are important determinants of genome stability in culture human lymphocytes. J. Nutr., v.134, p.48-56, 2004.

KIRSCH-VOLDERS, M.; SOFUNI, T.; AARDEMA, M.; ALBERTINI, S.; EASTMOND, D.; FENECH, M.; JR ISHIDATE, M.; KIRCHNER, S.; LORGE, E.; MORITA, T.; NORPPA, H.; SURRALLES; VANHAUWAERT, A.; WAKATA, A.. Corrigendum to "Report from the in vitro micronucleus assay working group". Mutat. Res., v.540, p.153-163, 2003.

KONAN, N.A.; BACCHI, E. M.; LINCOPAN, N.; VARELA, S.D.; VARANDA, E.A. Acute, subacute toxicity and genotoxic effect of a hydroethanolic extract of the cashew (Anacardium occidentale L.). J. Ethnopharmacol. v.110. p.30-38, 2007.
KRISHNA, G.; HAYASHI, M. In vivo rodent micronucleus assay: protocol, conduct and data interpretation. Mutat. Res., v.455, p.155-166, 2000.

LINDHOLM, C.; NORPPA, H.; HAYAHSI, M.; SORSA, M. Induction of micronuclei and anaphase aberrations by cytochalasin B in human lymphocyte cultures. Mutat. Res., Amsterdam, v.260, p.369-375, 1991.

LORENZI, H.; MATOS, J.F.A. Plantas medicinais no Brasil: nativas e exóticas cultivadas. São Paulo: Ed. Nova Odessa, Instituto Plantarum, 2002. 512 p.

MADLE, E.; KORTE, A.; BEEK, B. Species differences in mutagenicity testing: I. Micronucleus and SCE tests in rats, mice, and Chinese hamsters with aflatoxin B1. Teratog. Carcinog. Mutagen., v.6, p.1-13, 1986.

MACGREGOR, J.T. Dietary factors affecting spontaneous chromosomal damage in man. Prog. Clin. Biol. Res., v.347, p.139-153, 2005.

MACGREGOR, J.T.; HEDDLE, J.A.; HITE, M.; MARGOLIN, B.H.; RAMEL, C.; SALAMONE, M.F.; TICE, R.R.; WILD, D. Guidelines for the conduct of micronucleus assays in mammalian bone marrow erythrocytes. Mutat. Res., v.189, p.103-112, 1987.

MAHDI, E.S.; NOOR, A.M.; SAKEENA, M.H.; ABDULAH, G.Z.; ABDULKARIM, M.; SATTAR, M.A. Identification of phenolic compounds and assessment of in vitro antioxidants activity of $30 \%$ ethanolic extracts derived from two Phyllanthus species indigenous to Malaysia. Afr. J. Pharm. Pharmacol., v.5, n.17, p. 1967-1978, 2011.

MANJREKAR, A.P.; JISHA, V.; BAG, P.P.; ADHIKARY, B.; PAI, M.M.; HEDGE, A.; NANDINI, M. Effects of Phyllanthus niruri Linn. treatment on liver, kidney and testes in $\mathrm{CCl}_{4}$ induced hepatotoxic in rats. Ind. J. Exp. Biol., v.46, p.514-520, 2008.

MARTINS, E.R.; CASTRO, D.M.; CASTELLANI, D.C.; DIAS, J.E. Plantas medicinais. Universidade Federal de Viçosa, Imprensa Universitária, 1994. p.1-29.

MATTER, B.; SCHMID, W. Treminon-induced chromosomal damage in bone marrow cells of six mammalian species evaluated by the micronucleus test. Mutat. Res., v.12, n.4, p.417-425, 1971. 
MAVOURNIN, K.H.; BLAKEY, D.H.; CIMINO, M.C. The in vivo micronucleus assay in mammalian bone marrow and peripheral blood. A report of the U.S. Environmental Protection Agency Gene-Tox Program. Mutat. Res., v. 239, n.1, p.29-80, 1990.

MENDES, E.; HERDEIROS, M.T., PIMENTEL, F. O uso de terapêuticas à base de plantas por doentes oncológicos. Acta Med. Port., v.23, n.5, p.901-908, 2010.

MIGUEL, O.G.; MARTINS, J.D.G.R.; AMORIM, E.L.C.; ALBUQUERQUE, U.P. Chemical and preliminar analgesic evaluation of geraniin and furosin isolated from Phyllanthus sellowianus. Planta Med., v.62, n.2, p.146-149, 1996.

MONTEITH, D.K.; VANSTONE, J. Comparison of the microgel electrophoresis assay and other assays for genotoxicity in the detection of the DNA damage. Mutat. Res., v.345, n.3-4, p.97-103, 1995.

MOORE, F.R.; URNA, G.A.; KRISHNA, G.; THEISS, J.C. An in vivo/in vitro method for assessing micronucleus and chromosome aberration induction in rat bone marrow and spleen 1. Studies with cyclophosphamide. Mutat. Res., v.335, p.191-199, 1995.

MUÑOZ, V.; SAUVAIN, M.; BOURDY, G.; CALLAPA, J.; ROJAS, I.; VARGAS, L.; TAE, A.; DEHARO, E. The search for natural bioactive compounds through a multidisciplinary approach in Bolivia. Part II. Antimalarial activity of some plants used by Mosetene Indians. J. Ethnopharmacol., v.69, n.2, p.139-155, 2000.

NISHIURA, J.L.; CAMPOS, A.H.; BOIM, M.A.; HEILBERG, I.P.; SCHOR, N. Phyllanthus niruri normalizes elevated urinary calcium levels in calcium stone forming (CSF) patients. Urol. Res., v.32, p.362-366, 2004.

NOTKA, F.; MEIER, G. R.; WAGNER, R. Inhibition of wild-type human immunodeficiency virus and reverse transcriptase inhibitor-resistant by Phyllanthus amarus. Antiviral Res., v.58, p.175-186, 2003.

NWANJO, H.U.; OZE, G.. Hypoglycaemic and hypolipidaemic effects of phyllanthus niruri in streptozotocin-induced diabetic rats. J. Med. Lab. Sci., v.15, n.1, p.1744-49, 2006.

OGATA, T.; HIGUCHI, H.; MOCHIDA, S.; MATSUMOTO, H.; KATO, A.; ENDO, T.; KAJI, A.; KAJI, H. HIV-1 reverse transcriptase inhibitor from Phyllanthus niruri. AIDS. Res. Hum. Retrov., v.8, n.11, p.1937-1944, 1992.
PEREIRA, A.D.; ANDRADE, S.F.; SWERTS, M.S.O.; MAISTRO, E.L. First in vivo evaluation of the mutagenic effect of Brazilian green propolis by comet assay and micronucleus test. Food Chem. Toxicol., v.46, p.2580-2584, 2008.

PETTIT, G.R.; SCHAUFELBERGER, D.E. Isolation and structure of the cytostatic lignan glicoside phyllanthostatin A. J. Nat. Prod., v. 51, n.6, p. 1104-1112, 1988.

PETTIT, G.R.; SCHAUFELBERGER, D.E.; NIEMAN, R.A.; DUFRESNE, C.; SAENZ-RENAULD, J.A. Antineoplasic agents, Isolation and structure of phyllanthostatin. J. Nat. Prod., v.53, n.6, p.1406-1413, 1990.

POWIS, G., MOORE, D.J. High-performance liquid chromatographic assay for the antitumor glycoside phyllanthoside and its stability in plasma of several species. J. Chromatogr., v.342, p.129-134, 1985.

QUIAN-CUTRONE, J.; HUANG, S.; TRIMBLE, J.; LI, H.; LIN, P.F.; ALAM, M.; KLOHR, S.E.; KADOW, K.F. Niruriside, a new HIV REV/RRE binding inhibitor from Phyllanthus niruri. J. Nat. Prod., v.59, n.2, p.196-199, 1996.

RABELLO-GAY, M. N. Teste do Micronúcleo em medula óssea. In: RABELLO-GAY, M. N.; RODRIGUES, M. A. L. R.; MONTELEONE-NETO, R. (Eds.). Mutagênese, teratogênese e carcinogênese: métodos e critérios de avaliação. Ribeirão Preto: Sociedade Brasileira de Genética/ Revista Brasileira de Genética, 1991. 246 p.

RAJAGOPALAN, H.; JALLEPALLI, P.V.; RAGO, C.; VELCULESCU, V.E.; KINZLER, K.W.; VOGELSTEIN, B.; LENGAUER, C. Inactivation of hCDC4 can cause chromosomal instability. Nature, v.428, n.6978, p.77-81, 2004.

RAJESHKUMAR, N.V.; JOY, K.L.; GIRIJA, K.; RAMSEWAK, R.S.; NAIR, M.G.; RAMADASAN, K. Antitumour and anticarcinogenic activity of Phyllanthus amarus extract. $J$. Ethnopharmacol., v.81, p.17-22, 2002.

RAJESHKUMAR, N.V.; KUTTAN, R. Phyllanthus amarus extract administration increases the life span of rats with hepatocellular carcinoma. J. Ethnopharmacol., v.73, n.1-2, p. 215-219, 2000.

RANG, H.P.; DALE, M.M.; RITTER, J.M.; MOORE, P.K. Farmacologia. 5.ed. Rio de Janeiro: Elsevier, 2003. 904 p. 
RIBEIRO, L.R. Teste do micronúcleo em medula óssea de roedores in vivo. In: RIBEIRO, L.R.; SALVADORI, D.M.F.; MARQUES, E.K. (Eds.). Mutagênese ambiental. Canoas: ULBRA, 2003. cap.7, p.173-198.

SALAMONE, M.F.; HEDDLE, J.A.; STUART, E.; KATZ, M. Towards improved micronucleus test-studies on three model agents, mitomycin C, cyclophosphamide and dymethilbenzathracene. Mutat. Res., v.74, p.347-356, 1980.

SAMALI, A.; FLORENCE, D. T.; ODENIRAN, O. A.; CORDELIA, O.N. Evaluation of chemical constituents of Phyllanthus Niruri. Afr. J. Pharm. Pharmacol., v.6, n.3, p.125-128, 2012.

SANKAR, P.; TELANG, A.G.; MANIMARAN, A. Curcumin protects against cypermethrin-induced genotoxicity in rats. Environ. Toxicol. Pharmacol., v.30, n.3, p.289-291, 2010.

SANTOS, A.R.S.; FILHO, V.C.; YUNES, R.A.; CALIXTO, J.B. Analysis of the mechanisms underlying the antinociceptive effect of the extracts of plants from the genus Phyllanthus. Gen. Pharmacol., v.26, p.1499-1506, 1995.

SANTOS, A.R.S.; NIERO, R.; FILHO, V.C.; YUNES, R.A.; PIZZOLATTI, M.G.; MONACHE, F.D.; CALIXTO, J.B. Antinociceptive properties of extracts of new species of plants of the genus Phyllanthus. J. Nat. Prod., v.72, p.229238, 2000.

SANTOS, C.A.M.; TORRES, K.R.; LEONART, R. Plantas medicinais (herbarium, flora et scientia). São Paulo: Cone, 1987. p.11, 135.

SCHMID, W.; ARAKAKI, D.T.; BRESLAU, N.A.; CULBERTON, J.S. The Chinese hamster bone marrow as an in vivo test system I. Cytogenetics results on basics aspects of the methodology obtained with alkylating agents. Humangen. II, p.103-118, 1971.

SCHMID, W. Chemical mutagen testing on in vivo somatic mammalian cells. Agents Actions, v.3, p.77-85, 1973.

SCHMID, W. The micronucleus test. Mut. Res., v.31, p.9-15, 1975.

SCHMID, W. The micronucleus test for cytogenetics analysia. In: HOLLAENDER, A. (Ed.). Principles and methods for their detection. New York: Plenum Press, 1976. v.4, p.31-53.
SHYAMASUNDAR, K.V.; SINGH, B.; THAKUR, R.S.; HUSSAIN, A.; KISO, Y.; HIKINO, H. Antihepatotoxic principles of Phyllanthus niruri herbs. J. Ethnopharmacol., v.14, n.1, p. 41-44, 1985.

SILVA, M.I.G. Utilização de fitoterápicos nas Unidades Básicas de Saúde da Família (UBSF) no Município de MaracanaúCE. 2003. Fortaleza, 2003.144p. Dissertation of Master degree. College of Pharmacy, Dentistry and nursing. Federal university of Ceara.

SIMÕES, C.M.O.; MENTZ, L.A.; SCHENKEL, E.P.; IRGANG, B.E.; STEHMANN, J.R. Plantas da medicina popular no Rio Grande do Sul. 1.ed. Porto Alegre: UFRGS, 1986. p.60,72,73.

SPEIT, G.; ZELLER, J.; NEUSS, S. The in vivo or ex vivo origin of micronucleic measured in human biomonitoring studies. Mutagenesis, v.26, n.1, p.107-110, 2011.

SRIPANIDKULCHA I, B.; TAT TAWASART, U.; LAUPATARAKASEM, P.; VINITKETKUMNEUN, U.; SRIPANIDKULCHAI, K.; FURIHATA, C.; MATSUSHIMA, T. Antimutagenic and anticarcinogenic effects of Phyllanthus amarus. Phytomedicine, v.9, n.1, p.26-32, 2002.

SUZUKI, D.T.; GRIFFITHS, A.J.F.; MILLER, J.H.; LEWONTIN, R.C. Introdução à genética. 4.ed. Rio de Janeiro: Guanabara Koogan, 1992. 663 p.

TONA, L.; MESIA, K.; NGIMBI, N.P.; CHRIMWAMI, B.; OKOND, A.; CIMANGA, K.; DE BRUYNE, T.; APES, S.; HERMANS, N.; TOTTE, J.; PIETERS, L.; VLIETINCK, A.J. In vivo antimalarial activity of Cassia occidentalis, Morinda morindoides and Phyllanthus niruri. Ann. Trop. Med. Parasitol., v.95, p.47-57, 2001.

TUROLLA, M.S.R. Avaliação dos aspectos toxicológicos dos fitoterápicos: um estudo comparativo. 2004. São Paulo, 2004. 131 p. (Dissertation of Master degree in Pharmaceutical Sciences). College of Pharmaceutical Sciences. São Paulo University.

UENO, H.; HORIE, S.; NISHI, Y.; SHOGAWA, H.; KAWASAKI, M.; SUSUKI, S.; HAYASHI, T.; ARISAWA, M.; SHIMIZU, M.; YOSHIZAKI, M.; MORITA, N. Chemical and pharmaceutical studies on medicinal plants in Paraguay. Geraniin, an angiotensin-converting enzyme inhibitor from "Paraparai Mi", Phyllanthus niruri. J. Nat. Prod., v. 51, n.2, p. 357-359, 1988. 
UMEGAKI, K.; FENECH, M. Cytokinesis-block micronucleus assay in WIL2-NS cells: a sensitive system to detect chromosomal damage induced by reactive oxygen species and activated human neutrophils. Mutagenesis, v. 15, n.3, p.261-269, 2000.

VALADARES, M.C.; CASTRO, N.C.; CUNHA, L.C. Synadenium umbellatum: citotoxicidade e danos ao DNA de células da medula óssea de camundongos. Rev. Bras. Ciên. Farm., São Paulo, v.43, n.4, p.631-638, 2007.

VEIGA-JUNIOR, V.F. Estudo do consumo de plantas medicinais na Região Centro-Norte do Estado do Rio de Janeiro: aceitação pelos profissionais de saúde e modo de uso pela população. Rev. Bras. Farmacogn., v.18, p.308$313,2008$.

VENKATESWARAN, P.S.; MILLMAN, I.; BLUMBERG, B.S. Effects on an extract from Phyllanthus niruri on hepatitis B and woodchuck hepatitis viruses. in vitro and in vivo studies. Proc. Nat. Acad. Sci., v.84, p.274-278, 1987.
VINOD, V.; TIWARI, P.K.; MESHRAM, G.P. Evaluation of mutagenic and antimutagenic activities of neem (Azadirachta indica) seed oil in the in vitro Ames Salmonella/microsome assay and in vivo mouse bone marrow micronucleus test. J. Ethnopharmacol., v.134, n.3, p. 931-937, 2011.

WEI, W.; LI, X.; WANG, K.; ZHENG, Z.; SHOU, M. Lignans with Anti-Hepatitis B Virus Activities from Phyllanthus niruri L. Phytother. Res., v.26, n.7, p.964-968, 2012.

ZAMBRANO, M.A.; TARGA, H.J.; RABELLO-GAY, M.N. Phisiological saline solutions as a useful tool in micronucleus and metaphase slide preparations. Stain Technol., v.57, n.1, p.48-49, 1982.

Received for publication on $21^{\text {st }}$ June 2012 Accepted for publication on $02^{\text {nd }}$ November 2012 